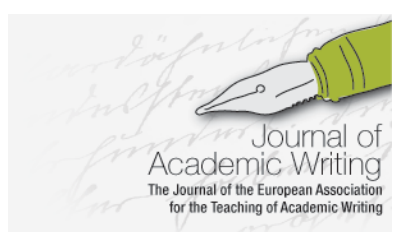

Journal of Academic Writing

Vol. 6 No 1 Autumn 2016, pages 98-107

http://dx.doi.org/10.18552/joaw.v6i1.286

\title{
Teaching Disciplinary Writing as Social Practice: Moving Beyond 'text-in-context' Designs in UK Higher Education
}

\author{
Simon J. Green \\ University of Leeds, UK
}

\begin{abstract}
This paper concerns the teaching of disciplinary academic writing in Higher Education in the UK and is motivated by the need to identify an EAP instructional design that will facilitate student writers' engagement with disciplinary writing as a situated social practice. In the paper I describe and critique what I characterise as a 'text-in-context' genre-based pedagogy influential in EAP provision in the UK, and then sketch out the broad parameters of a 'social practice' instructional design, enactable within the context of UK Higher Education.
\end{abstract}

\section{Introduction}

This paper is concerned with instructional design for English for Academic Purposes (EAP) within the context of Higher Education in the UK. It is motivated by the desire to find an instructional design to help student writers engage with academic writing as a situated social practice, and one enactable within the institutional separation of language/literacy provision from disciplinary study that characterises much of UK Higher Education. I argue that what is needed is an instructional design that integrates textual explication, contextual exploration and the development of literacy practices. In what follows, I firstly draw on recent work in Academic Literacies (Ivanič 1998, Lea and Street 1998, Lillis 2001) to outline a conception of academic writing as a situated social practice. I then discuss what I characterise as a 'text-incontext' instructional design, a genre-based pedagogy heavily influenced by Systemic Functional Linguistics (Kalantzis and Cope 2012, Martin 2009) and the English for Specific Purposes (ESP) tradition in genre studies (Bhatia 2004, Swales 1990), which has had a significant influence on EAP provision in the UK. I argue that although the textual explication this approach encourages is essential to writing pedagogy, the concern with texts rather than practices marginalises other, equally essential, aspects of writing. I then sketch out key features of a 'social practice' design, requiring some co-operation between EAP/literacy teachers and disciplinary academics but enactable within the institutional separation of language/literacy study from disciplinary studies, drawing especially on recent work in Rhetorical Genre Studies (Bawarshi and Reiff 2010, Devitt, Reiff, and Bawarshi 2004, Johns 2008, 2011, Johns et al. 2006).

\section{Student writing as a situated social practice}

In recent years, student writing has been widely constructed as a 'situated social practice', reflecting the impact of work in the New Rhetoric/Rhetorical Genre Studies (Bawarshi and Reiff 2010, Bazerman and Prior 2004, Berkenkotter and Huckin 1995, Freedman and Medway 1994) and Academic Literacies theory (Ivanič 1998, Lea and Street 1998, Lillis 2001). There are a number of implications of this view for the teaching of academic writing. Firstly, the notion of 'situation', the fact that student writing takes place within specific 
disciplinary and institutional communities (Swales 1990), at given levels of legitimate participation (Wenger 1998), and is shaped by the epistemologies and values of those communities, foregrounds the issue of specificity. If student writing is marked by specificity, academic writing provision must be similarly specific (Hyland 2002).

The concept of 'practice' (Lankshear and Knobel 2011) foregrounds a number of issues relevant to understanding student writing. The first is that social practices involve activities: people do things, alone or with others, and do so within activity systems, 'ongoing, objectdirected, historically conditioned, dialectically structured tool-mediated human interaction' (Russell 1997: 510). Students do not engage in writing in isolation or without affordances: they do so through interactions with lecturers, colleagues, administrative staff, librarians, texts of various kinds, digital tools, and within specific organisations of space and over time. The import of this is that students need to understand the activity systems they work within if they are to make use of their affordances and to work within their constraints.

The second issue is the interweaving of strands of knowledge, skill and technology that characterise any practice. Student writing requires knowledge of disciplinary concepts, an understanding of disciplinary and institutional values, familiarity with institutional systems and procedures, familiarity with relevant genres, mastery of register, relative mastery of process options appropriate to the task at hand, mastery over relevant digital and analogue technologies, and the ability to deploy a range of interpersonal and intercultural competencies (Beaufort 2004, Lea and Jones 2011, Tardy 2009). Again, academic writing support needs to acknowledge this complexity.

The third issue is 'object-orientation' in the sense that practices are directed at outcomes. Student writing, like all academic writing, is a practice of representing, constructing and communicating knowledge and so practices of argument (Wingate 2012a), the discoursal construction of identity (Ivanič 1998), and the projection of authority (Tang 2009) are central. However, student writing is also - and this is crucial to understanding how student writing differs from professional academic writing - a practice of knowledge display. The bulk of student writing is undertaken for the purposes of assessment (Catt and Gregory 2006) so student writers must know, but they must also show that they know. Adequate academic writing support needs to address all of these aspects of practice.

\section{Text-in-context: genre-based pedagogy in EAP in UK Higher Education}

Academic literacy provision in UK Higher Education presents a varied picture and it is important to avoid undue generalisation. While acknowledging the risk of this, I believe two features common to many UK contexts may be noted. Firstly, at the level of institutional organisation, the explicit teaching of academic writing largely remains the province of EAP/Academic Literacy teachers working from language centres, writing centres or academic support units, separated from disciplinary departments and often serving the literacy needs of international students and 'non-traditional' UK students (e.g. mature students) rather than student bodies as a whole. This organisation reflects two institutional assumptions. The first is that 'mainstream' students will be adequately socialised through the 'enabling context' (Freedman 1993) of lectures, seminars and tutorials so resources may be targeted at 'nonmainstream' students with 'literacy deficits'. The second is that literacy practices may be reduced to sets of generic skills which can be trained by non-disciplinary teachers (Ivanič and Lea 2006). Although both of these assumptions have been demolished in recent years (Lea and Street 1998, 2006, and more recently Wingate 2015) the institutional structures they motivated remain.

There are positive developments, influenced in part by the American Writing in the Disciplines movement. One is the incidence of disciplinary curricular initiatives in which disciplinary teachers make curricular space available for literacy work (for example Mitchell and Evison 2006), the other is less radical, but perhaps for that reason more likely to succeed within UK Higher Education. This is the increasing incidence of literacy programmes taught by EAP teachers but working within disciplines and with the co-operation of disciplinary teachers 
(Ahearn 2006, Ganobcsik-Williams 2006, Thomas 2013, Young and Avery 2006), a collaborative integration of language/literacy and content theorised by, for example Jacobs (2007) and Gustafsson and Jacobs (2013). The instructional design I suggest assumes such collaboration, though requiring relatively limited involvement by disciplinary academics.

Secondly, at the level of instructional design, EAP writing pedagogy has been heavily influenced by genre studies in the Systemic-Functional Linguistics (SFL) and the English for Specific Purposes (ESP) traditions (Bhatia 2004, Martin 2009, Swales 1990), and the 'visible pedagogies' of textual explication they have encouraged (for example Cheng 2008, Flowerdew 2002, Kalantzis and Cope 2012, Paltridge 2001). What has emerged from these influences is what I term a text-in-context model of genre-based pedagogy: that is, a pedagogy that seeks primarily to uncover the defining stages, moves and informational structures of key genres and to relate these to the contexts of culture and situation in which these texts are produced and consumed.

This text-in-context design is typified by the four-stage sequence developed within SFL (Cope and Kalantzis 1993, Feez 2002, Macken-Horarik 2002) which begins with an exploration of writing context, defined in terms of audience and communicative purpose, followed by the introduction and analysis of sample genre texts in terms of rhetorical structure, function and linguistic realisation. This 'deconstruction' stage is followed by 'construction' stages, first scaffolded and collaborative, then independent, and may include an element of process instruction. Tribble and Wingate have researched a sophisticated version of this at King's, London (Tribble 2015, Tribble and Wingate 2013, Wingate 2012b, Wingate and Tribble 2012). Their deconstruction stage requires students to work with samples of student responses to specific assignment questions, assessed at varying levels of performance, and annotated by disciplinary lecturers. Working with these texts offers students the chance to see, for example, what distinguishes a successful assignment introduction in a History essay from a weak one. As Wingate (2012b) has argued, the approach is genuinely disciplinary, helps learners with the specific assessed genres they have to write in, and is an instructional design requiring only limited co-operation from disciplinary staff, in the form of annotated, marked texts. More recently, Wingate (2015) has advanced an inclusive approach to scaffolding academic literacies, integrating practices and insights from RGS and Academic Literacies theory, in particular the semi-ethnographic exploration of writing contexts, and one relocating the locus of literacy work to disciplinary classrooms. Nevertheless, the primary focus remains on the scaffolded deconstruction and construction of disciplinary student texts.

I believe that even a sophisticated version of a text-in-context approach, such as Wingate (2015), remains vulnerable to criticisms made over many years from Rhetorical Genre Studies and Academic Literacies perspectives (Bawarshi and Reiff 2010, Devitt et al. 2004, Johns 2008, 2011, Lillis and Scott 2008). Two criticisms seem germane. The first is that in concentrating on the explication of specific genres or 'genre-acquisition' (Johns 2008, 2011, Johns et al. 2006), it fails to help student writers develop 'the rhetorical flexibility necessary for adapting their socio-cognitive genre knowledge to ever-evolving contexts' (Johns 2008: 238). What Johns and others refer to as a 'genre-awareness' pedagogy enables students to approach new and unfamiliar genres critically and with insight, primed with questions and exploratory tools. Wingate (2015) addresses this issue directly, arguing that the kind of analysis she advocates, in which students compare high-scoring and low-scoring realisations of specific genres (such as an undergraduate History essay) does constitute a genreawareness pedagogy. However, although I can see how this supports a subtle understanding of a specific genre, it is not clear to me that this approach really offers the 'rhetorical flexibility' across genres that Johns seeks.

The second is that in focusing on texts the approach marginalises practices (Lillis and Scott 2008). This is by no means a novel observation. Writing about text-in-context approaches twenty years ago, Berkenkotter and Huckin observed that:

[a] though such an approach enables one to make generalizations about [...] a genre's form, substance and context [...] it does not enable us to determine anything 
about the ways in which genre is embedded in the communicative activities of the members of a discipline (1995: 2 , italics in original).

While it is true that 'the conventions, intentions and assumptions of discourse communities are manifested in academic texts', the claim that 'it is through these texts that students will learn to understand the social practices of the discipline' (Wingate and Tribble 2012: 489) is only plausible up to a point. Firstly, this claim ignores the process dimension of practice: the fact that in order to create texts realising 'conventions, intentions and assumptions', students need to engage in a range of searching, reading and writing practices, engage with sequences of genres, interact with peers, tutors, administrators, use digital tools in specific ways, deploy strategies for developing and articulating arguments and so on. A finished text offers no insight into these. Secondly, the approach ignores some of the evidence on genre learning (Tardy 2006, 2009), in particular the necessity for writers to engage in actual, disciplinary genred writing, to structure and proceduralize nascent genre knowledge. Writers need to engage in practical genre writing in order to fully understand how to use genres.

\section{Teaching disciplinary writing as social practice}

In this section I want to sketch out the parameters of a social practice instructional design for teaching disciplinary academic writing enactable within the kind of setting discussed above where EAP teachers deliver a course with (some) co-operation of disciplinary academics. The assumption is that this kind of academic writing teaching would be delivered in the context of a free-standing academic literacy module taught to pre-sessional or in-sessional undergraduates as a complement to, or as an integral but non-assessed element of, a firstyear undergraduate degree programme. In advancing this I recognise that this kind of literacyfocused activity is best seen as just a step along the way to a position in which literacy and content studies are fully integrated and in which curricula space, academic workloads, and job-descriptions and resources are restructured accordingly. However, as Wingate (2015) acknowledges, such radical changes may be some way off in the UK.

The instructional design I want to outline, firstly, builds upon the understanding of academic writing as a social practice constructed in the first section. Secondly, it integrates three key elements of the text-in-context approach: extensive exploration of the writing context, analysis and guided noticing of genre features, and scaffolded construction of texts. Thirdly, it integrates insights from genre-awareness pedagogies developed within Rhetorical Genre Studies (Devitt et al. 2004, Johns 2008 and 2011), and aspects of practice suggested by applications of Academic Literacies theory, specifically the role of tutor-student dialogue (Lillis 2006). I shall outline the approach in terms of focus and process.

\section{Focus}

The conception of academic writing as a social practice suggests a very extensive list of possible foci for a disciplinary academic writing programme, a list I consider under the following broad headings: context, practice, and genre. This lengthy but far from exhaustive list may go some way to showing how much a text-in-context genre-based pedagogy might potentially miss or at least not prioritise.

I am using the term 'context' broadly to cover a range of matters, disciplinary and institutional, at the level of organisation of teaching and learning and at the anterior level of ethos, and also matters of affordance. Under 'ethos' I bracket matters such as the epistemological values of the disciplinary/institutional community, and prevailing conceptions of academic integrity, learning, and the roles of students and academics. The list could go on but what I am getting at here are the fundamental, largely tacit, values of a disciplinary/institutional community which structure how people behave, and which new entrants must begin to uncover if they are to survive. Things like written assessment criteria are indicative of these, but students need help in uncovering the layers of meaning within them. Under 'organisation' I bracket all of the administrative and teaching/learning systems in place, many of which may be accessible through handbooks, administrative web-pages and so on. Under 'affordance' I include study resources (libraries, online resources, access to digital technologies for study purposes) and 
also things like study and personal support systems (such as student counsellors). Given the complexity of the overlapping activity systems of an academic community, and the largely implicit nature of the ethical dimension, it is essential, as Casanave and others have argued (Casanave 2009, Casanave and $\mathrm{Li}$ 2008) that students be encouraged and helped to investigate their community in a semi-ethnographic way.

Under 'practice', I include anything that a student will need to do to effect the completion of an assessed piece of writing. The process may begin with constructing an understanding of what an assignment question requires, through for example, iterative reading and reflection and discussion with peers or tutors, and writing to establish a base-line understanding, before reading in the literature. It will almost certainly involve grappling with a literature, and so involve practices of literature searching, maintaining a source management database such as an EndNote library, and making and working with notes to map the positions in a debate, and to develop a perspective. It may also involve practices such as 'writerly reading', that is reading with an eye to form as well as content (Hirvela 2004) or for example the analysis of genre-exemplars (Wingate 2012b). It is likely to involve iterative outlining and drafting to articulate an argument (Wingate 2012a), an authorial perspective (Tang 2009), and construct an authorial identity (Ivanič 1998). It is likely also to involve the use of a range of digital tools (Lea and Jones 2011) and implicate a range of interpersonal interactions with peers or tutors or administrators.

Under 'genre' I include, of course, the assessed written genres of the programme, as far as they can be sampled. However, a social practice approach must also show how genres are integrated in sets in determinate ways (Bhatia 2004) so, for example, a student working on an assignment may annotate the assignment question, may make or annotate a reading list, will make notes on sources in various ways, may maintain a 'thoughts' diary to capture ideas, will make an outline and then drafts and so on. The finished assignment is always part of a set of other genres, and students need to be helped to see how one genre relates to another.

I would also argue, following Johns $(2008,2011)$ and Devitt et al. $(2004)$ that the treatment of genre needs to move beyond the specific assessed genre at hand in order to try to address issues of genre in general through equipping students with tools to investigate and interrogate new genres that they meet. There are now well-developed and empirically based 'macrogenre' frameworks, such as Carter (2007) and classifications of genre families (Nesi and Gardner 2012), that can be used in the ways Johns (2011) suggests to prompt comparison and reflection and so support genre-awareness.

Finally, Bawarshi (2003) has argued that we need to see 'invention', i.e. the development of a message as a process of situated cognition, which means that working out what to say in a particular assignment means working with and within the genre. Exploring the genre is a way of working out what meanings to make as well as how to make them. The treatment of genre needs to help students understand this.

\section{Process}

There are various viable process options so I shall limit this discussion to elements of process that are essential to the kind of social practice pedagogy I envisage and I shall sketch these out here. The first is that work on situated academic writing must commence with some exploration of the institutional and disciplinary situation. In most Higher Education institutions new students receive briefings on the administrative, teaching, and learning systems that will regulate their studies, probably with recourse to documentation like programme, school or level handbooks and other related texts. In my own university this is very much a transmission of information, though students are welcome to follow up matters they do not understand. This, however, does little to clarify the context at the level of ethos. Although investigating documents may help here - particularly assessment criteria - it is likely that it is only through observing and asking questions that students will begin to discern deeper levels of meaning in the behaviour they see. I would argue that the most economical way of doing this is through a scaffolded semi-ethnographic exploration. The kinds of genre-related context-exploration activities Reiff (in Johns et al. 2006) suggests might help but I am thinking here chiefly of priming students and equipping them with task-sheets that require them to interview 
academics, higher-level students and administrators to gain insights into, for example, academic integrity, or core values like criticality.

The second element, drawing on insights into genre-learning (Tardy 2009), is that to begin to develop a mastery over disciplinary practice and genre, students must be posed with a challenge that closely resembles the challenges they will face in writing for assessment in their studies. So they need to be posed with an assignment of roughly the kind they will face, requiring the use of the practices they will need to engage in, in order to produce a text to be marked to community standards by disciplinary academics. (A similar suggestion for a practice assignment is made, in fact, in Wingate 2015, though this is separated from the genre-analysis work she advocates). This is the first area where the co-operation of disciplinary academics is required. The writing of the assignment will be scaffolded by EAP teachers but they have to have a disciplinary assignment to work with, so one written by disciplinary academics and accompanied by briefing materials. Further, disciplinary staff will need to respond to a sample of draft work for each student, and they will need to mark and to comment on the assignment texts the students ultimately produce. This is an investment of time on their part but it is a very much smaller investment than that required in, say, a teamteaching project (Dudley-Evans and St. John 1988), and the possible pay-off in terms of student literacy is obvious.

This assignment may be considered as a core project, work on which will continue throughout the course. Work on this project would need to be scaffolded (Woods, Bruner, and Ross 1976), that is, having posed the assignment task teachers must engage in a systematic scaffolding of the work through helping students unpack the assignment question and work out what it is asking them to do, helping them identify a series of tasks to be carried out in order to complete the assignment, helping them turn that into a feasible schedule, facilitating the sharing of ideas and the development of arguments, and facilitating the development and sharing of outlines and drafts.

The third key element is the modelling of literacy practices and genres, for example, looking at Carter's (2007) work on macro-genres, relevant samples from Nesi and Gardner's (2012) genre-families, deconstructing and constructing arguments, looking at how a writer can engage with sources to project authority, carrying out a literature search, analysing the assignment genre in terms of overall purpose, marker expectations, functional stages, moves, linguistic realisations and so on. This work is best carried out in a series of discrete sessions and it is in these that the kind of genre-focused analytical activities that form the core of textin-context teaching have a vital role, and also the kind of exploratory, interrogative genreawareness work suggested by Johns and others (Bawarshi and Reiff 2010, Johns 2008, 2011, Johns et al. 2006). These discrete sessions would feed in to the ongoing work on the assignment and the experience of the assignment would feed back into the discrete sessions. It might therefore be best to consider the relationship between these two strands, the discrete sessions and the scaffolded writing project, as like a double helix: the two strands weave around each other affording links and connections in various ways.

\section{Concluding remarks}

In this paper I have considered the limitations of what I have referred to as a 'text-in-context' instructional design for EAP in Higher Education in the UK and have attempted to sketch out the parameters of a 'social practice' design for teaching disciplinary academic writing. This design integrates the analytical activities central to text-in-context within a broadly focused design, seeking to help new students explore their disciplinary and institutional academic context, and to develop a preliminary understanding of, and facility with, the practices and genres with which they must engage in their studies. This design is based on the assumption of a level of co-operation between disciplinary academics with regard to the setting and marking of student assignments and the provision of annotated disciplinary assignment texts for analysis, and is constituted by the interweaving in a double-helix of work on a scaffolded assignment-writing project with work on discrete aspects of disciplinary literacy practice and genre. As a design that achieves disciplinary specificity of focus, offers students both analysis 
of, and practical engagement in, disciplinary literacy practices, and requires relatively little cooperation from disciplinary academics, it may offer a viable solution to the need for a social practice pedagogy enactable by EAP teachers.

\section{Acknowledgements}

I am very grateful to the editors and the two anonymous reviewers for their thoughtful and insightful comments on earlier drafts of this work. 


\section{References}

Ahearn, A. (2006). 'Engineering Writing: Replacing "Writing Classes" with a "Writing Imperative"'. in Teaching Academic Writing in UK Higher Education. ed. by Ganobcsik-Williams, L.. Basingstoke: Palgrave Macmillan, 110-123

Bawarshi, A., and Reiff, M. J. (2010) Genre: An Introduction to History, Theory, Research and Pedagogy. West Lafayette, Ind.: Parlor Press

Bazerman, C., and Prior, P. (2004) What Writing Does and How It Does It: An Introduction to Analyzing Texts and Textual Practices. Mahwah, N.J: Lawrence Erlbaum Associates

Beaufort, A. (2004) 'Developmental Gains of a History Major: A Case for Building a Theory of Disciplinary Writing Expertise'. Research in the Teaching of English 39, 136-185

Berkenkotter, C., and Huckin, T. (1995) Genre Knowledge in Disciplinary Communication: Cognition/Culture/Power. Hillsdale, NJ: Lawrence Erlbaum

Bhatia, V. J. (2004) Worlds of Written Discourse. London: Continuum

Carter, M. (2007) 'Ways of Knowing, Doing, and Writing in the Disciplines'. College Composition and Communication 58 (3), 385-418

Casanave, C. P. (2009) Writing Games. London: Routledge

Casanave, C. P., and Li, X. (eds.) (2008) Learning the Literacy Practices of Graduate School: Insiders Reflections on Academic Enculturation. Ann Arbor: University of Michigan Press

Catt, R., and Gregory, G. (2006) 'The Point of Writing: Is Student Writing Developed or Merely Assessed?'. in Teaching Academic Writing in UK Higher Education. ed. by Ganobcsik-Williams, L. Basingstoke: Palgrave Macmillan, 16-29

Cheng, A. (2008) 'Analyzing Genre Exemplars in Preparation for Writing: The Case of an L2 Graduate Student in the ESP Genre-Based Instructional Framework of Academic Literacy'. Applied Linguistics 29 (1), 50-71

Cope, B., and Kalantzis, M. (1993) The Powers of Literacy: A Genre Approach to Teaching Writing. London: Falmer

Devitt, A., Reiff, M. J., and Bawarshi, A. (2004) Scenes of Writing: Strategies for Composing with Genres. New York: Addison Wesley Longman

Dudley-Evans, T., and St. John, M. J. (1988) Developments in English for Specific Purposes. Cambridge: Cambridge University Press

Feez, S. (2002) 'Heritage and Innovation in Second Language Education'. in Genre in the Classroom, ed. by Johns, A. Mahwah, NJ: Lawrence Erlbaum, 43-69

Flowerdew, J. (2002) 'Genre in the Classroom: A Linguistic Approach'. in Genre in the Classroom, ed. by Johns, A. Mahwaw, NJ: Lawrence Erlbaum, 91-102

Freedman, A. (1993) 'Show and Tell? The Role of Explicit Teaching in the Learning of New Genres'. Research in the Teaching of English 27 (3), 222-251

Freedman, A., and Medway, P. (1994) Genre in the New Rhetoric (Vol. 1). Hoboken: Taylor and Francis 
Ganobcsik-Williams, A. (2006) 'Building an Academic Writing Programme from within a Discipline'. in Teaching Academic Writing in UK Higher Education. ed. by GanobcsikWilliams, L. Basingstoke: Palgrave Macmillan , 98-109

Gustafsson, M., and Jacobs, C. (2013) 'Editorial: Student Learning and ICLHE - Frameworks and Contexts'. Journal of Academic Writing 3 (1), ii-xii

Hirvela, A. (2004) Connecting Reading and Writing in Second Language Writing Instruction. Ann Arbour: University of Michigan Press

Hyland, K. (2002) 'Specificity Revisited: How Far Should We Go Now?'. English for Specific Purposes 21 (4), 385-395

Ivanič, R. (1998) Writing and Identity. Amsterdam: John Benjamins

Ivanič, R., and Lea, M. R. (2006) 'New Contexts, New Challenges: The Teaching of Writing in UK Higher Education'. in Teaching Academic Writing in UK Higher Education. ed. by Ganobcsik-Williams, L. Basingstoke: Palgrave Macmillan, 6-15

Jacobs, C. (2007) 'Towards a Critical Understanding of the Teaching of Discipline-Specific Academic Literacies: Making the Tacit Explicit'. Journal of Education 41, 59-81

Johns, A. (2011) 'The Future of Genre in L2 Writing: Fundamental, but Contested, Instructional Decisions '. Journal of Second Language Writing 20, 56-68

Johns, A. (2008). 'Genre Awareness for the Novice Academic Student: An Ongoing Quest'. Language Teaching 41(2), 237 - 252

Johns, A., Bawarshi, A., Coe, R. M., Hyland, K., Paltridge, B., Reiff, M. J., and Tardy, C. (2006) 'Crossing the Boundaries of Genre Studies: Commentaries by Experts'. Journal of Second Language Writing 15, 234-249

Kalantzis, M., and Cope, B. (2012) Literacies. Cambridge: Cambridge University Press

Lankshear, C., and Knobel, M. (2011) New Literacies: Everyday Practices and Social Learning. Maidenhead: Open University Press

Lea, M. R., and Jones, S. (2011) 'Digital Literacies in Higher Education: Exploring Textual and Technological Practice'. Studies in Higher Education 36 (4), 377-393

Lea, M. R., and Street, B. V. (2006) 'The "Academic Literacies" Model: Theory and Applications'. Theory into Practice 45 (4), 368-377

Lea, M. R., and Street, B. V. (1998). 'Student Writing in Higher Education: An Academic Literacies Approach'. Studies in Higher Education 23 (2), 157-172

Lillis, T. (2006) 'Moving Towards an 'Academic Literacies' Pedagogy: Dialogues of Participation'. in Teaching Academic Writing in UK Higher Education. ed. by Ganobcsik-Williams, L. Basingstoke: Palgrave Macmillan, 30-45

Lillis, T. (2001) Student Writing: Access, Regulation, Desire. New York: Routledge.

Lillis, T., and Scott, M. (2008) 'Defining Academic Literacies Research: Issues of Epistemology, Ideology and Strategy'. Journal of Applied Linguistics 4 (1)

Macken-Horarik, M. (2002) '"Something to Shoot For": A Systemic Functionalist Approach to Teaching Genre in Secondary School Science'. in Genre in the Classroom, ed. by Johns, A. Mahwah, NJ: Lawrence Erlbaum, 17-42 
Martin, J. (2009) 'Genre and Language Learning: A Social Semiotic Perspective'. Linguistics and Education 20 (1), 10-21

Mitchell, M., and Evison, A. (2006) 'Exploiting the Potential of Writing for Educational Change at Queen Mary, University of London'. in Teaching Academic Writing in UK Higher Education. ed. by Ganobcsik-Williams, L. Basingstoke: Palgrave Macmillan, 68-84

Nesi, H., and Gardner, S. (2012) Genres across the Disciplines: Student Writing in Higher Education. Cambridge: Cambridge University Press

Paltridge, B. (2001) Genre and the Language Learning Classroom. Ann Arbor: University of Michigan Press

Russell, D. R. (1997) 'Rethinking Genre in School and Society: An Activity Theory Analysis'. Written Communication 14 (4), 504-554

Swales, J. (1990) Genre Analysis: English in Academic and Research Settings. Cambridge: Cambridge University Press

Tang, R. (2009) 'A Dialogic Account of Authority in Academic Writing'. Academic Writing: At the Interface of Corpus and Discourse, ed. by Charles, M, Pecorari, D., and Hunston, S. . London: Continuum, 170-188

Tardy, C. (2009) Building Genre Knowledge. West Lafayette: Parlor Press

Tardy, C. (2006) 'Researching First and Second Language Genre Learning: A Comparative Review and a Look Ahead'. Journal of Second Language Writing 15 (2), 79-101

Thomas, P. (2013) 'Transformation, Dialogue and Collaboration: Developing Studio-Based Concept Writing in Art and Design through Embedded Interventions'. Journal of Academic Writing 3 (1), 42-66

Tribble, C. (2015) 'Writing Academic English Further Along the Road. What Is Happening Now in EAP Writing Instruction?'. ELT Journal 69 (4), 442-462

Tribble, C., and Wingate, U. (2013) 'From Text to Corpus: A Genre-Based Approach to Academic Literacy Instruction'. System 41 (2), 307-321

Wenger, E. (1998) Communities of Practice: Learning, Meaning, and Identity. Cambridge: Cambridge University Press

Wingate, U. (2015) Academic Literacy and Student Diversity. Bristol: Multilingual Matters

Wingate, U. (2012a) '"Argument!" Helping Students Understand What Essay Writing Is About'. Journal of English for Academic Purposes 11 (2), 145-154

Wingate, U. (2012b) 'Using Academic Literacies and Genre-Based Models for Academic Writing Instruction: A "Literacy" Journey'. Journal of English for Academic Purposes $11(1), 26-37$

Wingate, U., and Tribble, C. (2012) 'The Best of Both Worlds? Towards an English for Academic Purposes/Academic Literacies Writing Pedagogy'. Studies in Higher Education 37 (4), 481-495

Woods, D., Bruner, J., and Ross, G. (1976) 'The Role of Tutoring in Problem Solving'. Journal of Child Psychology and Psychiatry 17, 89-100

Young, T., and Avery, S. (2006) 'Teaching Writing within a Discipline: The Speak-Write Project'. in Teaching Academic Writing in UK Higher Education. ed. by GanobcsikWilliams, L. Basingstoke: Palgrave Macmillan, 85-97 